\title{
Retribusi Pengelolaan Sampah Dalam Menakar Kesiapan Diet Sampah Plastik Warga Batam
}

\author{
Adi Irawan Setiyanto", Riri Zelmiyanti" and Arif Darmawan* \\ *Politeknik Negeri Batam \\ Jurusan Manajemen Bisnis \\ Jl. Ahmad Yani, Batam Centre, Batam 29461, Indonesia \\ E-mail: riri@polibatam.ac.id
}

\begin{abstract}
Abstrak
Penelitian ini bertujuan untuk melihat perilaku masyarakat Batam dalam pengelolaan sampah dan kesiapan warga Batam dalam menerapkan diet sampah plastik. Metode yang digunakan dalam penelitian ini adalah deskriptif analisis dengan mengamati dan menyebarkan kuesioner. Manfaat praktis yang diinginkan setelah melakukan penelitian dapat mendorong masyarakat untuk mengurangi jumlah produksi sampah dan berguna bagi pengambil kebijakan dalam mengevaluasi kebijakan yang telah dilaksanakan. Dari data yang diperoleh, $74 \%$ masyarakat Batam menggunakan jasa pengelolaan sampah. Sebanyak 209 responden atau 52,3\% masyarakat Batam memahami istilah diet plastik, hampir separuh masyarakatnya tidak mengetahui tentang diet plastik. 92,8\% masyarakat Batam mengetahui tentang bahaya sampah plastik bagi lingkungan, sehingga dibutuhkan upaya yang maksimal agar masyarakat mengetahui cara mengurangi penggunaan plastik. Permasalahan utama dalam pengelolaan sampah bermula dari: sampah yang diambil petugas tidak dipilah, kurangnya penyuluhan dari pengelola sampah. $98 \%$ responden bersedia mengurangi sampah plastik, oleh karena itu pemerintah harus terus mensosialisasikan cara-cara mengurangi penggunaan plastik.
\end{abstract}

Kata kunci: Sampah, Plastik, dan Manajemen

\begin{abstract}
This study aims to see the behavior of the Batam community in waste management and the readiness of Batam citizens in implementing a plastic waste diet. The method used in this research is descriptive analysis by observing and distributing questionnaires. The practical benefits that are wanted after conducting research to encourage people to reduce the amount of waste production and are useful for policy makers in evaluating policies that have been implemented. From the data obtained, $74 \%$ of Batam people use waste management services. As many as 209 respondents or 52.3\% of the people of Batam understand the term plastic diet, almost half of the people do not know about the plastic diet. $92.8 \%$ of Batam people know about the dangers of plastic waste for the environment, so it takes maximum effort so that people know how to reduce plastic use. The main problems in waste management stem from: waste taken by officers is not sorted, lack of counseling from waste managers. $98 \%$ of respondents are willing to reduce plastic waste, therefore the government must continue to socialize ways to reduce plastic use.
\end{abstract}

Keywords: Waste, Plastics, and Management

\section{Pendahuluan}

Salah satu pendapatan daerah bersumber dari retribusi daerah, total retribusi daerah kota Batam pada tahun 2018 sebesar 94.581.392.967,00 sedangkan tahun 2019 menurun menjadi 90.511.150.389,64 (Laporan RAPBD kota Batam). Retribusi sampah yang dipungut terhadap masyarakat Batam kisaran Rp7.000, - sampai Rp 50.000, - tergantung luas bangunan, aturan biaya retribusi sampah diatur dalam Perda Persampahan Kota Batam. Retribusi tersebut salah satu penggunaannya untuk pengelolaan sampah. Jika dilihat dari anggaran yang disediakan pemerintah kota Batam melalui Dinas Lingkungan Hidup (DLH) sebesar 97 Milliar untuk pengelolaan sampah di Batam selama 2017

(https://batampos.co.id/2017/01/23/anggaran-sampahbatam-tahun-2017-rp-97-miliarr)

Herman Rozie selaku Kepala Dinas Lingkungan Hidup (DLH) Kota Batam menyatakan bahwa warga Kota Batam menghasilkan 900 ton sampah setiap harinya. Sekitar 20 persen dari jumlah tersebut diperkirakan sampah plastik. Saat ini pemerintah baru mencoba menerapkan kebijakan kantong plastik tidak gratis per 01 Maret 2019 (Haryanti, Dewi. 2019). Di sisi lain jika 
dilihat dari ketersediaan Tempat Pembuangan Akhir (TPA) Batam memiliki lokasi pembuangan sampah di telaga punggur dengan luas $46,8 \mathrm{H}$, dari total luasnya $24,3 \mathrm{H}$ yang digunakan untuk pengelolaan sampah. Jika pengelolaan sampah tidak ditanggani dengan baik sekitar 6 tahun Batam tidak memiliki lahan untuk TPA (Maulana, Hadi. 2017).

Pengelolaan sampah merupakan salah satu factor penting yang perlu diperhatikan. Sebagai salah satu daerah perbatasan langsung dengan negara tetangga yang perkembangan cukup pesat, menempatkan kota Batam sebagai gerbang pembagunan daerah dan nasional. Oleh karena itu potensi atau peluang yang dimiliki kota Batam harus didukung dengan kebersihan wilayahnya. Akan tetapi banyaknya regulasi yang mengatur mengenai pengeloaan sampah ternyata belum mampu mengurangi produksi sampah dikota Batam.

Peraturan mengenai pengelolaan sampah di Indonesia sudah banyak seperti undang-undang (UU) Nomor 18 tahun 2008 tentang pengelolaa sampah, peraturan pemerintah (PP) 81 tahun 2012 tentang sampah rumah tangga. Peraturan presiden Nomor 83 tahun 2018 tentang penanganan sampah laut. Sejumlah strategi dilakukan antara lain gerakan nasional mendorong kesadaran terkait bahaya sampah plastik, perbaikan pengelolaan sampah, serta mengatasi sampah dipesisir dan laut. Selain regulasi tingkat Nasional berbagai daerah juga mengeluarkan peraturan daerah salah satu contohnya kota Batam. Di kota Batam terdapat peraturan pemerintah daerah (Perda) nomor 11 tahun 2013 tentang pengelolaan sampah. Berbagai masalah dan upaya yang telah dilakukan pemerintah untuk mengurangi jumlah sampah plastik ternyata belum mampu mengurangi produksi sampah di Kota Batam, oleh itu perlu dilakukan penelitian mengenai kesiapan warga Batam untuk menjalankan diet sampah plastik.

\section{Tinjauan Pustaka}

Berdasarkan pernyataan World Health Organization (WHO) sampah merupakan barang yang bersumber dari kegiatan manusia dipakai, tidak digunakan, tidak disukai atau yang dibuang. Sedangkan berdasarkan KBBI sampah merupakan benda yang dibuang tidak terpakai lagi seperti kotoran daun, dan kertas. Kesimpulan dari beberapa definisi di atas sampah merupakan barang atau benda dibuang berasal dari kegiatan manusia tidak lagi digunakan.

Sampah dapat diklasifikasikan dalam berbagai kelompok diantaranya:

1. Sampah menurut sumbernya (sampah yang berasal dari manusia, alam, nuklir, industri, dan prtambangan).

2. Sampah menurut sifatnya (sampah organik dan sampah anorganik).
3. Sampah menurut bentuknya (sampah padat dan sampah cair).

Gelberk dkk (1996) ada tiga dampak sampah terhadap masyarakat diantaranya:

1. Kesehatan (berbagai Penyakit diare, kolera, tifus, cacingan ataupun jamur).

2. Lingkungan: aliran air tidak lancar dan jangka panjang berdampak terjadinya banjir, sampah juga bau yang tidak sedap.

3. Sosial dan ekonomi. Penangan sampah yang tidak tepat bisa meningkatkan biaya kesehatan karena timbulnya penyakit.

Merujuk informasi dari departemen pekerjaan umum kota Semarang (2008), penanganan sampah dapat dilakukan dengan pengolahan sampah $3 \mathrm{R}$ yaitu:

1. Reuse (Menggunakan kembali) barang yang sudah menjadi sampah dapat digunakan Kembali baik dari fungsi yang sama atau fungsi lain contohnya kantong plastic bisa digunakan untuk membungkus makanan lagi atau digunakan untuk kerajinan tangan.

2. Reduce (Mengurangi) dapat dilakukan dengan meminimalisir penggunakan minuman botol plastic sekali pakai dengan menggunakan botol minum isi ulang. Misalnya Ketika mau jalan bawa minuman dari rumah.

3. Recycle (Daur ulang) daur ulang dapat dilakukan dengan menggunakan plastic kemasan makanan untuk tas belanja.

Gerakan Indonesia diet kantong plastik merupakan suatu perkumpulan social yang mengajak masyarakat lebih bijak dalam menggunakan kantong plastik. Diet plastik maksudnya selektif dalam mengkonsumsi. Tujuan dari kampanye diet kantong plastik untuk mengurangi penggunaan kantong plastik. Berikut beberapa bahaya kantong plastik:

1. Pembakaran dapat memunculkan zat-zat beracun dan berbahaya untuk manusia

2. Terurai lama sekitar 100 tahun sedangkan pemakaiannya terlalu cepat oleh konsumen

3. Mengotori lingkungan

4. Bahan baku sulit diperoleh dan termasuk energi yang tidak terbarukan.

Regulasi yang mengatur tentang pengelolaan sampah:

1. Undang-undang (UU) no 18 tahun 2008 tentang pengelolaan sampah

Berdasarkan UU no 18 tahun 2008, sampah yang dikelola sesuai UU terdiri atas: sampah khusus, 
sampah sekitar tempat tinggal serta sampah homogen rumah tangga. Pengelolaan sampah bertujuan buat mempertinggi Kesehatan rakyan dan kualitas lingkungan hidup. UU ini juga mengatur mengenai tugas serta kewenangan pemerintah dalam mengelola sampah, hak dan kewajiban rakyat pada pengelolaan sampah.

2. Berdasarkan Peraturan pemerintah (PP) 81 tahun 2012 tentang sampah rumah tangga

Maksud dari sampah rumah tangga merupakan Sampah yang bersumber dari kegiatan sehari-hari pada rumah tangga, tidak termasuk tinja dan sampah spesifik Pengaturan disini meliputi mengatur tentang kebijakan dan strategi pengelolaan sampah, pengelolaan sampah, kompensasi, pengembangan dan penerapan teknologi, sistem informasi, peran masyarakat serta pembinaan.

3. Peraturan Presiden no 18 tahun 2018 tentang penanganan sampah laut

Sampah laut merupakan sampah yang berasal dari daratan, badan air, dan pesisir yang mengalir ke laut atau sampah yang berasal dari kegiatan di laut. sedangkan sampah plastik adalah sampah yang mengandung senyawa polimer. Penanganan sampah laut perlu menentukan strategi program, dan kegiatan yang strategis, terukur, dan terarah untuk mengurangi jumlah sampah di laut terutama sampah plastik dalam bentuk aksi nyata.

4. Peraturan pemerintah daerah (Perda) nomor 11 tahun 2013 tentang pengelolaan sampah.

Pengelolaan sampah merupakan Tindakan yang systematis, menyeluruh dan dan berkesinanmbungan untuk mengurangi jumlah sampah. Peraturan ini mengatur tentang pengelolaan sampah, asas pengelolaan sampah, tugas dan wewenang pemerintah daerah dalam pengelolaan sampah, serta hak dan kewajiban masyarakat dalam pengelolaan sampah.

\section{Metode Penelitian}

\subsection{Lokasi dan Objek Penelitian}

Penelitian ini dilakukan di Kota Batam, untuk seluruh kecamatan.

\subsection{Jenis dan Sumber Data}

Penelitian ini merupakan penelitian deskriptif. Penelitian deskriptif merupakan penelitian yang mendeskripsikan suatu kejala, peristiwa, kejadian terjadi sekarang. Pada Penelitian deskriptif peneliti berusaha mendeskripsikan peristiwa dan kejadian yang menjadi pusat perhatian tanpa memberikan perlakuan khusus terhadap kejadian.

\subsection{Metode Pengumpulan Data}

Pengumpulan data dilakukan selama empat bulan, yaitu Mei - Agustus 2019. Pengumpulan data dilakukan dengan cara wawancara dan penyebaran kuisioner terhadap responden per-Kecamatan di Kota Batam. Metode pengambilan sampel menggunakan metode Stratified random sampling. Pada stratified random sampling elemen populasi dikelompokkan pada tingkatan-tingkatan tertentu dengan tujuan pengambilan sampel akan merata pada seluruh tingkatan dan sampel mewakili karakter seluruh elemen populasi yang heterogen, tingkatan yang digunakan dalam penelitian ini menggunakan dasar geografis wilayah berdasarkan kecamatan yang ada di Batam.

Rumus Slovin digunakan dalam penentuan jumlah sampel pada penelitian ini. Rumus Solvin yaitu sebuah rumus atau formula untuk menghitung jumlah sampel minimal apabila perilaku dari sebuah populasi tidak diketahui secara pasti. Rumus slovin biasanya digunakan dalam penelitian survey, biasanya jumlah sampel besar sekali, sehingga diperlukan sebuah formula untuk mendapatkan sampel yang sedikit tetapi dapat mewakili keseluruhan populasi.

Rumus Slovin sebagai berikut:

$$
n=\frac{N}{1+N e^{2}}
$$

Dari notasi di atas, $\mathrm{n}$ merupakan jumlah sampel minimal, nilai $\mathrm{N}$ populasi sedangkan nilai e error margin. Penelitian ini menetapkan besar sampel minimal berdasarkan tingkat kesalahan atau margin of error $5 \%$ atau confidence level $95 \%$. Berdasarkan hasil perhitungan rumus Slovin maka untuk sampel jumlah penduduk yang digunakan sebesar 400 responden.

\section{Hasil Penelitian}

Penelitian ini dilaksanakan dari bulan Mei 2019 sampai dengan November 2019. Penyebaran kuesioner menggunakan google form. Responden yang terlibat pada penelitian ini sebanyak 400 responden yang tersebar di 12 Kecamatan di Batam, dengan sebaran sebagai berikut: 


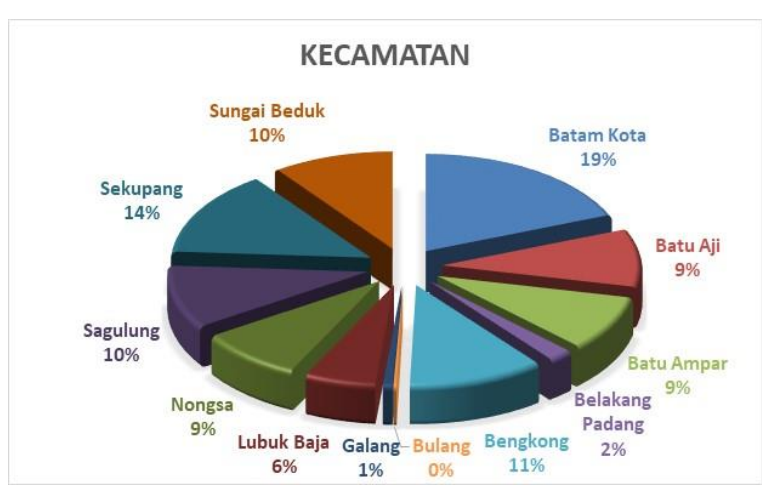

Gambar 1: Grafik sebaran kecamatan responden

Sebaran kuesioner untuk kelurahan bisa dilihat pada grafik berikut ini:

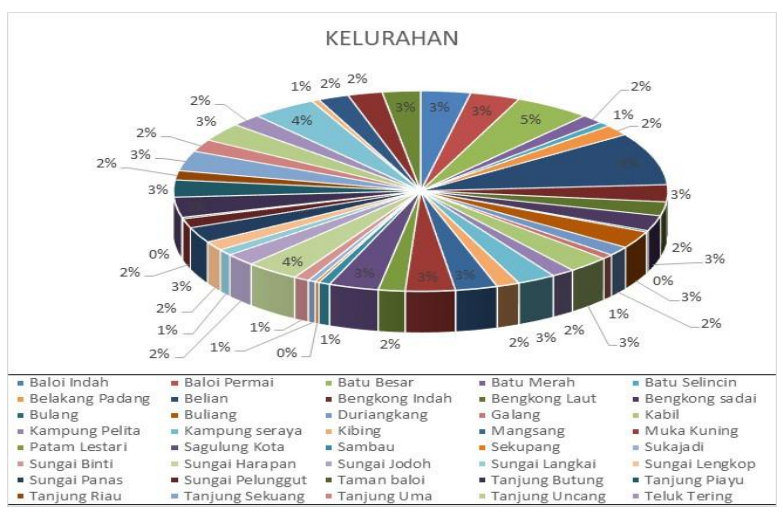

Gambar 2: Grafik sebaran kelurahan

Informasi tentang produksi sampah. Menghasilkan sampah atau tidak:

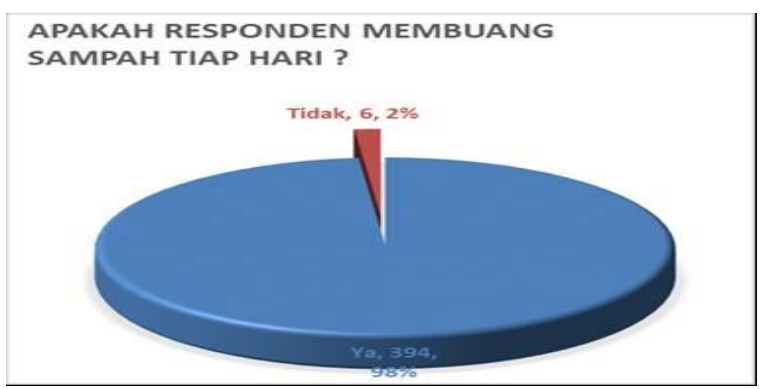

Gambar 3: Grafik produksi sampah responden

Sebanyak 394 responden atau 98\% membuang sampah setiap hari sedangkan sisanya $2 \%$ atau 6 orang tidak membuang sampah setiap hari.

Informasi tentang Program Diet Plastik dan Pengelolaan Sampah. Pengetahuan Masyarakat Tentang Program Diet Plastik

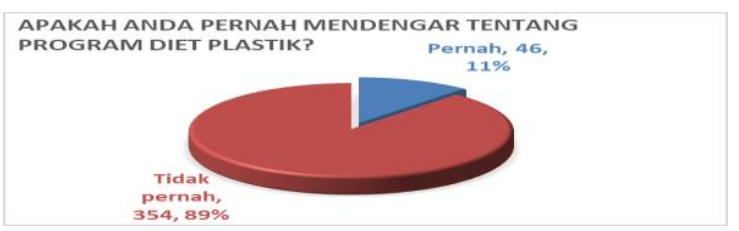

Gambar 4: Grafik sebaran responden yang pernah mendengar tentang program diet plastik
Masyarakat Batam yang sudah pernah mendengar mengenai Program diet plastic sudah cukup banyak hal tersebut bisa dilihat dari grafik di atas sebanyak 354 responden atau $89 \%$ responden sudah pernah mendengar tentang diet plastic Cuma sekitar $11 \%$ yang belum perah mendengar tentang diet plastik.

Pemahaman Masyarakat tentang Program Diet Plastik:

\section{APAKAH ANDA MEMAHAMI ATAU \\ MENGETAHUI ISTILAH DIET PLASTIK?}

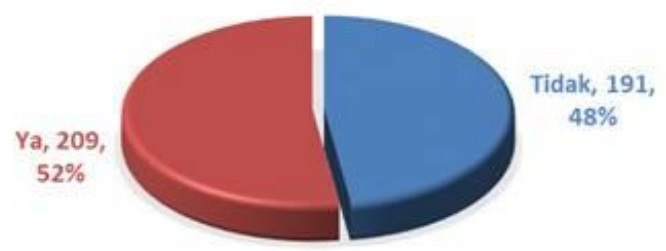

Gambar 5: Grafik sebaran responden yang memiliki pemahaman tentang diet plastik

Walaupun sudah banyak masyarakat Batam yang pernah mendengar tentang diet plastik ternyata masih banyak masyarakat yang belum mengetahui tentang istilah diet plastik sebanyak 191 responden atau $48 \%$ tidak mengetahui diet plastik.

Pengetahuan Masyarakat tentang Bahaya Limbah Plastik Bagi Lingkungan:

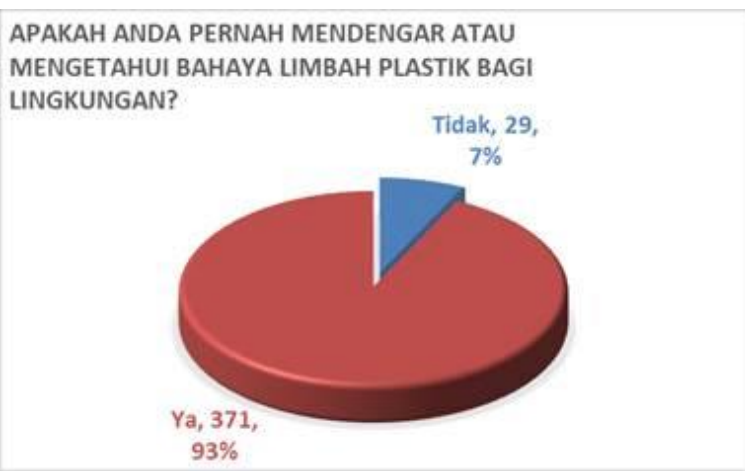

Gambar 6: Grafik sebaran pengetahuan responden tentang bahaya limbah plastik

Secara garis besar masyarakat Batam atau sebanyak 371 responden $93 \%$ pernah mengetahui bahaya limbah plastic dan sisanya $7 \%$ atau 29 orang masih belum mengetahui bahaya limbah plastik.

\section{Pengelolaan Sampah Plastik}

Penelitian ini melihat bagaimana pengelolaan sampah plastik dengan mengajukan pertanyaan-pertanyaan berikut:

1. Apakah anda pernah memisahkan sampah plastik dengan sampah lainya

Jumlah masyarakat kota Batam yang tidak

125 | Jurnal Akuntansi, Ekonomi dan Manajemen Bisnis | Vol. 9 No.2, December 2021, 122-129 | E-ISSN: 2548-9836 
memisahkan sampah plastik dibandingkan dengan yang memisahkan sampah plastik lebih banyak. Hal tersebut tergambar dari diagaram di atas sebanyak 217 responden atau $54 \%$ tidak memisahkan sampah plastik dengan sampah lainnya. Responden yang memisahkan sampah plastik dengan sampah lainnya sebanyak 183 responden atau $46 \%$.

\section{APAKAH ANDA PERNAH MEMISAHKAN SAMPAH} PLASTIK DENGAN SAMPAH LAINYA?

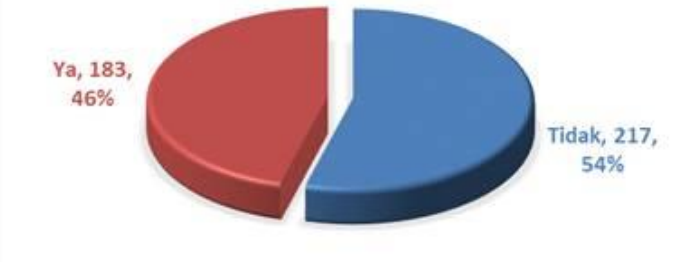

Gambar 7: Grafik sebaran responden yang memisahkan jenis sampah

2. Seberapa sering anda membawa tas belanja sendiri ketika berbelanja

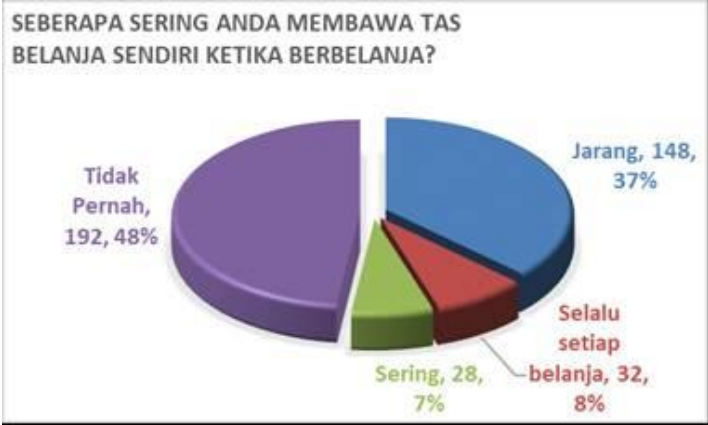

Gambar 8: Grafik sebaran responden yang membawa tas belanja sendiri ketika belanja

Grafik di atas menunjukan bahwa masih banyak masyarakat yang belum membawa tas belanja sendiri, jika dilihat dari jawaban responden 192 orang responden atau $48 \%$ menjawab tidak pernah membawa tas belanja, 148 responden jarang membawa tas plastic. Responden yang sering dan selalu mambawa tas plastik setiap belanja hanyak sebanyak totalnya $15 \%$ atau 50 responden.

3. Seberapa sering anda menggunakan sedotan dan tas kresek plastik

Dilihat dari grafik di atas sebanyak 172 responden atau $43 \%$ responden sering menggunakan sedotan dan tas kresek plastik, 140 orang atau 35\% responden jarang menggunakan, yang selalu mengunakan sedotan dan tas plastik sebanyak 54 orang atau $13 \%$ responden yang menjawab tidak pernah mengunakan sedotan dan tas kresek plastik sebanyak 34 orang atau $9 \%$.

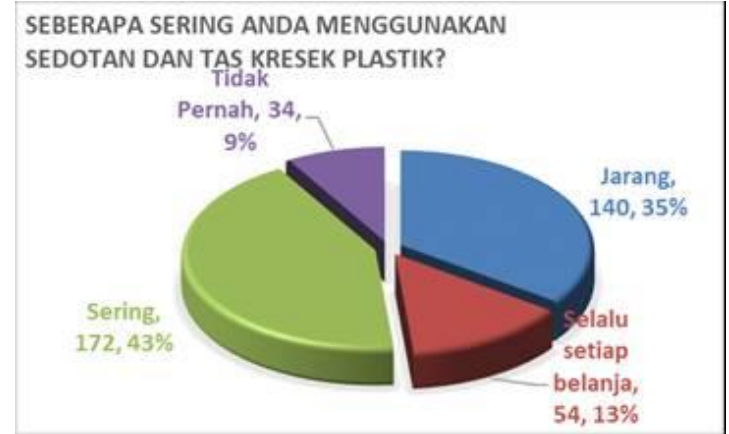

Gambar 9: Grafik sebaran frekuensi responden menggunakan sedotan dan tas kresek

4. Apakah anda mengetahui tentang sampah organik dan non-organik

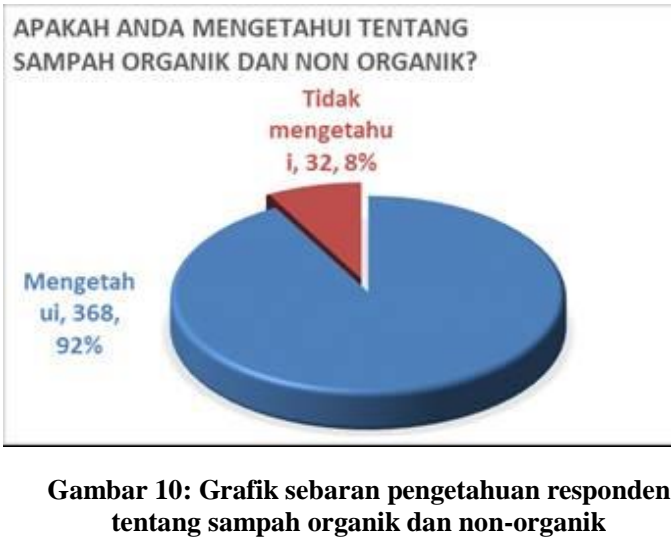

Banyak masyarakat kota Batam yang sudah mengetahui tentang sampah organik dan non-organik sebanyak 368 responden atau 92\% menjawab sudah mengetahui sedangkan $8 \%$ atau 32 orang tidak mengetahui sampah organik dan non-organik.

5. Seberapa seringkah anda/keluarga memilah sampah organik dan non-organik

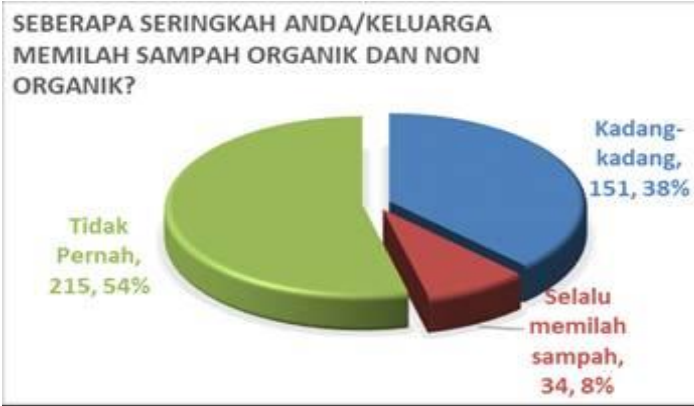

Gambar 11: Grafik sebaran frekuensi responden tentang memilah sampah organik dan non-organik

Lebih dari 54\% atau 215 responden tidak memilah sampah organik dan non-organik, responden yang selalu memilah sampah sebanyak 34 responden atau $8 \%$ responden sedangkan sisanya 151 responden atau 38\% kadang-kadang memilih sampah organik dan non-organik. 
6. Pernahkah anda/keluarga melakukan pengolahan sampah rumah tangga?

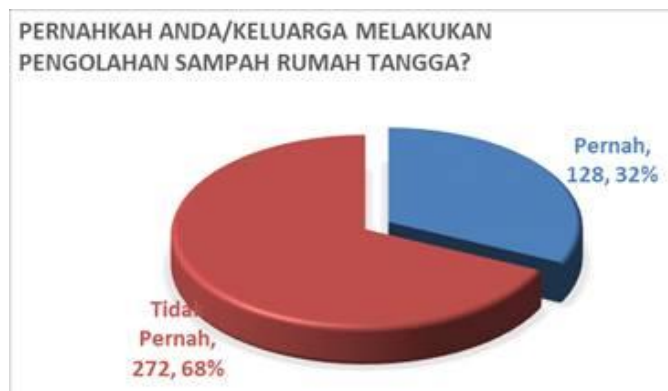

Gambar 12: Grafik sebaran responden tentang pengolahan sampah rumah tangga

Dari 400 responden penelitian ini banyak responden yang tidak pernah melakukan pengelolaan sampah sebanyak $68 \%$ atau 272 responden tidak mengolah sampah rumah tanggganya, sedangkan sisanya 128 responden pernah melakukan pengelolaan sampah.

7. Jika pernah, dalam bentuk apakah pengolahan sampah rumah tangga?

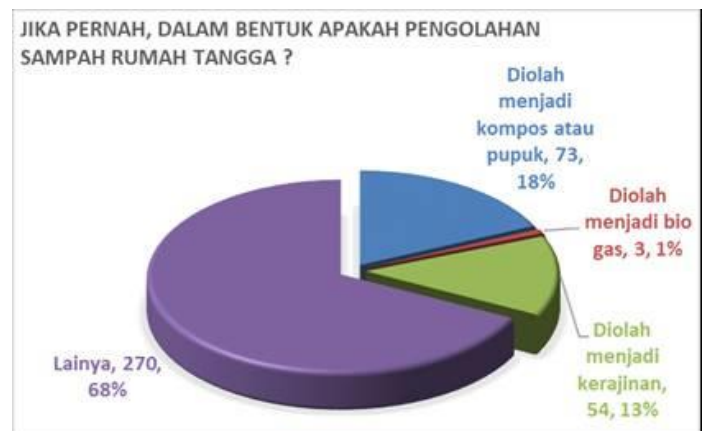

Gambar 13: Grafik sebaran bentuk olahan sampah rumah tangga

Pengolahan sampah rumah tangga oleh masyarakat Batam selama ini untuk $18 \%$ diolah menjadi kompos atau pupuk, 13\% diolah menjadi kerajinan, satu persen diolah menjadi biogas dan sisanya $68 \%$ diolah lainnya.

Kesiapan Masyarakat Mengurangi sampah Plastik

Untuk melihat kesiapan masyarakat di lihat dari beberapa pertanyaan berikut:

Apakah anda bersedia menggurangi sampah terutama sampah plastik?

Responden yang bersedia mengurangi sampah plastik sebanyak 394 orang dan yang tidak bersedia untuk mengurangi sampah plastic sebanyak 4 orang atau $1 \%$ sendangkan lainnya difikir-fikir dulu sebanyak 2 orang atau 1 persen.

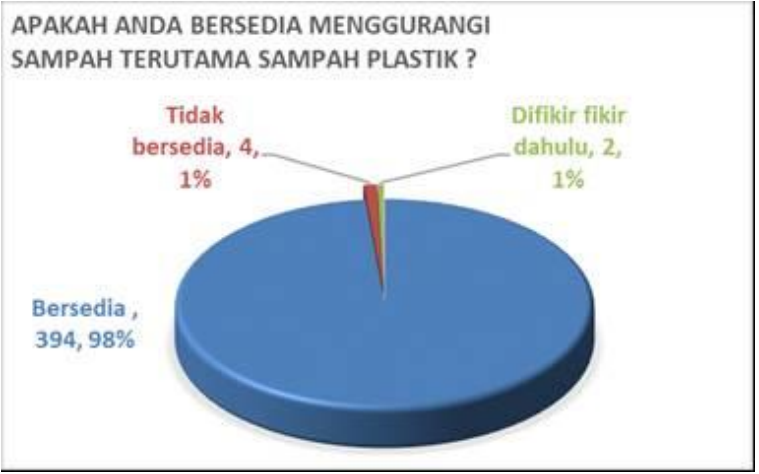

Gambar 14: Grafik sebaran kesediaan responden mengurangi sampah rumah tangga

Hal dilakukan untuk mengurangi sampah plastic:

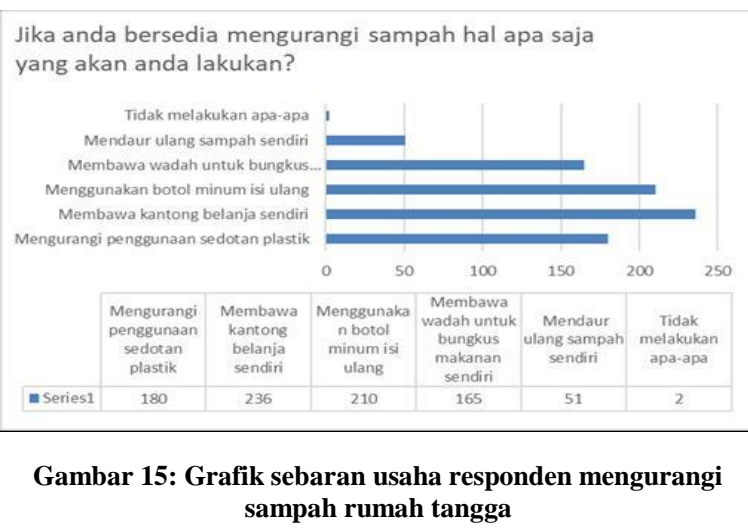

Grafik di atas menunjukan tindakan yang akan dilakukan masyarakat untuk mengurangi sampah plastik, setiap responden di beri kebebasan untuk menjawal lebih dari satu pilihan. Tindakan yang paling banyak dilakukan responden adalah dengan memilih membawa kantong belanjaan sendiri dan memilih membawa botol minum sendiri.

Pengetahuan Masyarakat tentang Bank Sampah

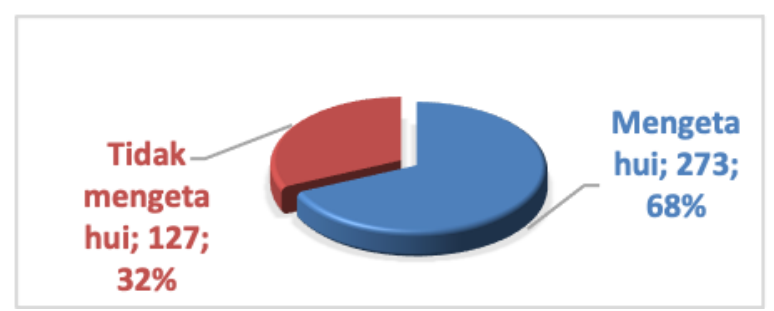

Gambar 16: Grafik sebaran pengetahuan responden tentang bank sampah

Sebanyak 273 responden atau $68 \%$ responden menjawab mengetahui tentang bank sampah, sisanya 127 orang responden tidak mengetahui bank sampah disini masih dibutuhkan sosialisasi lebih lanjut tentang bank sampah. Berikut data tentang tempat pengelolaan sampah di lingkungan sekitar. 


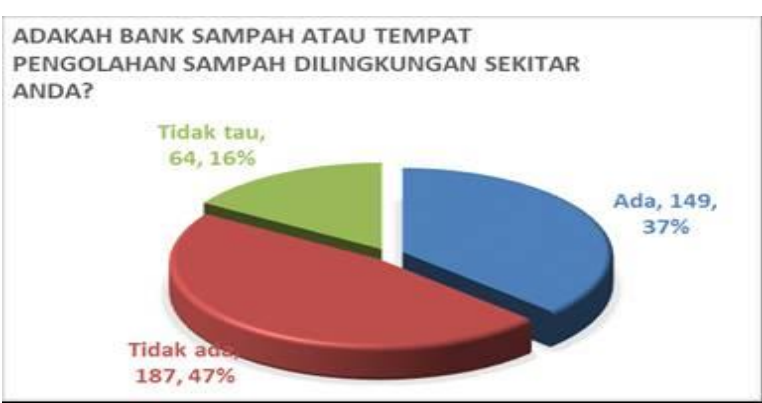

Gambar 17: Grafik sebaran ketersediaan bank sampah disekitar lingkingan

Ketersediaan tempat pengelolaan sampah di masyarakat masih sangat kurang hal ini bisa dilihat dari jawaban responden yang menjawab tidak adanya tempat pengelolaan sampah sebanyak 187 responden atau $47 \%$, yang memiliki tempat pengelolaan sampah Cuma $37 \%$ atau 149 responden sisanya 64 responden atau $16 \%$ menjawab tidak tahu.

Masalah utama dalam Pengelolaan Sampah di lingkungan:

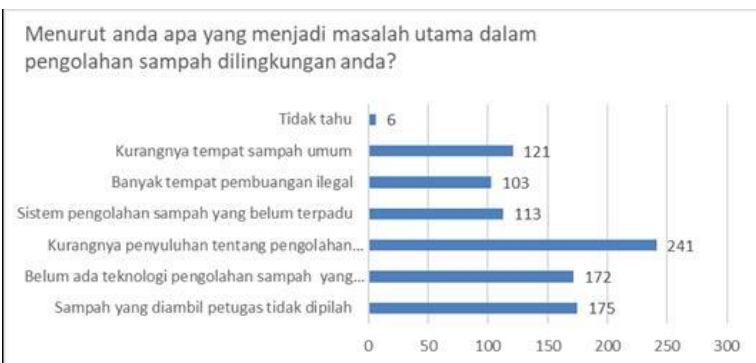

Gambar 18: Grafik sebaran pendapat responden mengenai masalah utama pengelolaan sampah

Dari pertanyaan kuesioner di atas setiap responden di beri kebebasan untuk memilih lebih dari satu jawaban. Data di atas menunjukan bahwa 241 responden menjawab kurangnya penyuluhan tentang pengelolaan sampah dan sampah yang di ambil petugas tidak di pilih padahal jika dilihat dari anggaran dana yang disediakan pemerintah untuk pengelolaan sampah ini cukup banyak. Oleh karena itu dibutuhkan usaha yang maksimila supaya ancaman dampak dari sampah tidak terjadi.

Kesediaan Masyarakat untuk Menjadi Kader dalam Pengelolaan Sampah Plastik

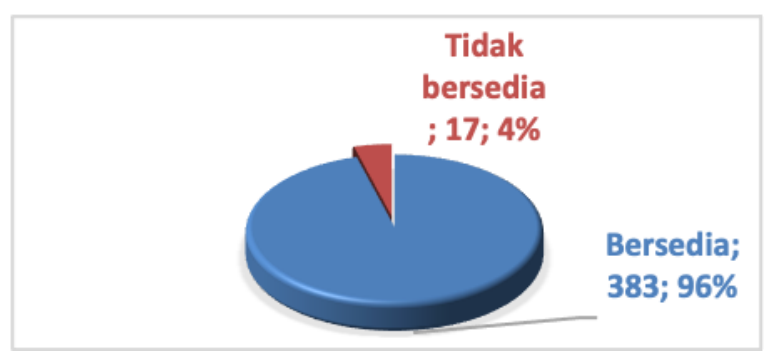

Gambar 20: Grafik sebaran kesediaan responden untuk menjadi kader pengelolaan sampah plastik
Diagram di atas menunjukan dibutuhkannya program bank sampah di masyarakat. Hal ini didukung dengan data jawaban responden yang bersedia untuk mengikuti program bank sampah sebanyak $96 \%$ atau 383 , karena hanya $4 \%$ yang menjawab tidak bersedia.

\section{Kesimpulan}

Berdasarkan hasil pengujian dalam penelitian ini dapat disimpulkan hal-hal sebagai berikut:

1) Sampah yang dihasilkan masyarakat sehari sekitar $0,5 \mathrm{~kg}$ sampai $7 \mathrm{Kg}$ perhari, jika dilihat dari ketersediaan lahan pengelolaan sampah tidak bisa di tamping untuk beberapa tahun jika tidak dikelola secara serius.

2) Banyak masyarakat yang menggunakan jasa pengelolaan sampah, dari data yang diperoleh $74 \%$ masyarakat Batam menggunakan jasa pengelolaan sampah.

3) Sebanyak 209 responden atau 52,3\% masyarakat Batam memahami tentang istilah diet plastik, hampir setengah dari masyakat belum tahu tentang diet plastik.

4) $92,8 \%$ masyarakat Batam mengetahui tentang bahaya limbah plastik bagi lingkungan, sehingga dibutuhkan usaha yang maksimal agar masyarakat mengetahui tentang cara mengurangi penggunaan plastik.

5) Pengelolaan mengenai sampah selama ini masih kurang terlihat dari masih kurangnya pemisahaan sampah plastik dengan sampah lainnya, $48 \%$ responden tidak pernah membawa tas belanja sendiri, $43 \%$ responden sering menggunakan sedotan dan tas plastik dan responden yang pernah melakukan pengolaan sampah rumah tangga hanya sebanyak $32 \%$.

6) $98 \%$ responden bersedia mengurangi sampah plastik oleh karena itu pemerintah harus terus mensosialisasikan cara mengurangi penggunaan plastik.

7) Masalah utama pengelolaan sampah bersumber dari: sampah yang diambil petugas tidak dipilah, kurangnya penyuluhan dari pengelola sampah.

8) Rata-rata masyarakat bersedia menjadi kader perubahan dalam pengelolaan sampah terutama sampah plastik.

\section{Daftar Pustaka}

A. Arif, Ahmad. "Dunia atasi sampah plastic". Kompas Rabu 13 Maret 2019 Halaman 10. 2019. 
B. Arif, Ahmad. 2019. Kaum Muda menuntut atasi perubahan Iklim. Kompas 16 Maret 2019. Halaman 8.

C. Haryanti,

Dewi.

http://batam.tribunnews.com/2019/03/01/tiap -hari-warga-batam-hasilkan-900-ton-sampahini-kata-kepala-dlh-soal-sampah-plastik, (22 Maret 2019). 2019..

D. Maulana,

Hadi https://regional.kompas.com/read/2017/12/13 /09371741/batam-terancam-krisis-lahan-pem buangan-sampah., (22 Maret 2019). 2019.

E. Pati, Kiki Andi. 2018.m https://regional.kompas.com/read/2018/11/20 /14571691/sampah-plastik-59-kg-ditemukandalam-perut-paus-yang-mati-di-wakatobi, 22 Maret 2019.

F. Peraturan pemerintah (PP) 81 tahun 2012 tentang sampah rumah tangga

G. Peraturan pemerintah daerah (Perda) nomor 11 tahun 2013 tentang pengelolaan sampah.

H. Peraturan daerah kota batam nomor 5 tahun 2001 tentang kebersihan Kota Batam.

I. Peraturan Presiden Republik Indonesia No.83 Tahun 2018 tentang Pananganan Sampah Laut.

J. Susanto, Ichwan. Janji anak pulau untuk kurangi sampah plastik. Kompas 2 februari 2019. Halaman 01.

K. http://dietkantongplastik.info/tentang-kami/

L. Undang-undang (UU) no 18 tahun 2008 tentang pengelolaan sampah

M. https://batampos.co.id/2017/01/23/anggaran-sam pah-batam-tahun-2017-rp-97-miliarr

N. Peraturan Daerah Kota Batam no 5 tentang kebersihan Kota Batam. 2001. 